\title{
THE ROLE OF TEACHER ASSOCIATION REGIONAL ON ISLAMIC RELIGIOUS EDUCATION IN SELAYAR ISLANDS
}

\author{
Dudi Hermawan, A. Marjuni, Muh. Rapi \\ UIN Alauddin Makassar \\ Jln H. M. Yasin Limpo No. 36 Samata, Gowa \\ Email: hdudi3267@gmail.com; hmarjunij@yahoo.com; \\ mrapi@uin-alauddin.ac.id
}

\begin{abstract}
This paper discusses the Professional Competence of Teachers in Selayar Islands Regency.The purpose of this study was to determine the form of professional competence of PAI (Islamic education) teachers in Selayar Islands Regency. In addition, Islamic education teacher association (AGPAI) contribution in developing the professional competence of PAI teachers in the Selayar Islands Regency. Furthermore, the results of the professional competence development of PAI teachers in the Selayar Islands Regency. This type of research is a descriptive qualitative case study in the Selayar Islands Regency. The results of this study show that the form of professional competence of PAI teachers is seen from various assessments including mastery of materials, structures, concepts, and scientific mindsets that support PAI subjects.
\end{abstract}

Keywords: Competence, Association, Professional, Assessment

\section{INTRODUCTION}

Association of Teachers of Religious Education is commonly abbreviated AGPAII an institution for the teachers who have the background and being subjects to 
pursue religious education Islam completely eradicated. Based on preliminary observations of researchers, found the data containing the activities of featuring material improvement of the competence of religious education teachers Islam completely eradicated as well as a place for religious education teachers Islam completely eradicated to establish friendship and close relationship that was initiated by the Governing Council of Regional Association of Teachers of Religious Education Islam completely eradicated Indonesia (AGPAII ) Selayar Islands Regency. ${ }^{1}$ Therefore, researchers are interested in submitting a title related to AGPAII.

The advancement of science and the increasingly rapid development of technology is a challenge for religious life and requires GPAI to be able to play an active role in displaying religious values that are comprehensive, dynamic and encourage and direct the dynamics of life according to the progress and challenges of the times it faces. GPAI is also required to develop professional abilities so that they are able to work and excel, both in carrying out daily tasks at school and in taking part in society, nation and state. ${ }^{2}$

The geographical condition of the archipelago, the large number of schools and GPAI, demands a more effective and efficient communication system and GPAI competency development. In order to support the improvement of these competencies, it is necessary to have a forum that functions as a vehicle for communication, information, insight development, performance and career of GPAI. So, the

${ }^{1}$ Observation, Thursday, Selayar, 17 September, 2020.

${ }^{2}$ Dewan Pengurus Pusat (DPP) Asosiasi Guru Pendidikan Agama Islâm Indonesia, Anggaran Dasar dan Anggaran Rumah Tangga AGPAII, p, 1 
existence of the AGPAII professional organization is very necessary. ${ }^{3}$

The reason that underlies this research process is the phenomenon where aspects of competency development do not get much attention, space, and time for many educators. Finally, more and more students drop out with a teacher education background but that does not guarantee the transformation of religious education at all.

The importance of this research lies in the substance in the learning process where teacher competence is very important because the objectives, educational programs, delivery systems, evaluations, and so on, should be planned in such a way as to be relevant to the demands of teacher competence in general. Thus, the teacher is expected to be able to carry out his duties and responsibilities as well as possible.

\section{THEORETICAL FRAMEWORK}

\section{Teacher Professionalism}

In Arabic, competence is called kafaah, and also alabliyah, which means having the ability and skills in the field so that he has the authority or authority to do something within the limits of his knowledge. ${ }^{4}$ Competence is always based on rationality which is carried out with full awareness of the "why" and "how" of the act. ${ }^{5}$

A person's competence is not only shown by the quantity of work, but also by the quality of work. Wina

${ }^{3}$ Dewan Pengurus Pusat (DPP) Asosiasi Guru Pendidikan Agama Islâm Indonesia, Anggaran Dasar dan Anggaran Rumah Tangga AGPAII, p. 1 .

${ }^{4}$ Herman Zaini, Kompetensi Guru PAI (Palembang: Noer Fikri Offset, 2015), p. 1.

${ }^{5}$ E. Mulyasa, Menjadi Guru Profesional; Menciptakan Pembelajaran Kreatif dan Menyenangkan (Cet. V; Bandung: Remaja Rosdakarya, 2007), h. 188. 
Sanjaya argues, competence is a person's rational behavior that is used to achieve goals whose requirements are in accordance with the expected conditions. ${ }^{6}$

Teacher professionalism is considered to play an important role in helping the development of students to realize their life goals optimally. Because only a professional teacher, he is able to carry out his duties and functions optimally in fostering the noble character of students. A necessity will arise because humans are weak and helpless creatures, which in their development always need other people, as well as students. Students need the role of other people, in this case are teachers who can foster, guide, and direct, so that students gain knowledge as a guide for their lives. $^{7}$

Professionalism is a person's professional attitude which means he does something as a main job, and not as a mere leisure time filler. A professional has the meaning of an expert (expert) with the knowledge he has in serving his work. Responsible for his decisions, both intellectual and behavioral, and have a sense of camaraderie, upholding professional ethics in a dynamic organization. A professional provides job services in a structured and orderly manner. This can be seen from personal tasks that reflect a person, which consists of self-concept, ideas that arise from oneself, and reality or reality from oneself. ${ }^{8}$

In Permendiknas RI No. 16 of 2007 concerning teacher competency standards states that "the professional competencies of teachers are:

1) Mastering the material, structure, concept, and scientific mindset that supports the subjects taught.

${ }^{6}$ Wina Sanjaya, Strategi Pembelajaran Berorientasi Standar Proses Pendidikan (Cet. II; Jakarta: Kencana, 2006), p. 55.

${ }^{7}$ E. Mulyasa, Standar Kompetensi dan Sertifikasi Guru (Bandung: Remaja Rosdakarya, 2012), p. 35-36.

${ }^{8}$ Syaiful Sagala, Kemampuan Profesional Guru dan Tenaga Kependidikan (Bandung: Alfabeta, 2011), p. 1. 
2) Mastering competency standards and basic competencies of the subjects taught.

3) Develop creatively guided learning materials.

4) Develop professionalism in a sustainable manner by taking reflective actions, and

5) Utilizing information and communication technology to develop themselves".

According to Arif, a teacher is considered competent if: 1) The teacher is able to develop responsibilities as well as possible 2) The teacher is able to carry out his roles successfully 3) The teacher is able to work in an effort to achieve the goals of school education 4) The teacher is able to carry out his role in the learning process. learn to teach at school. ${ }^{10}$

To professionalize a job, including the profession as a teacher, Wilensky formulated five steps, namely as follows:

1) Bring up a full-time or full-time job, not a part -time job.

2) Determine the school as a place to undergo the education or training process.

3) Establish a professional association.

4) Political agitation to fight for legal protection for the association or association.

5) Adopt formally the established code of ethics. ${ }^{11}$

According to Hamzah B. Uno said that the professional competence of teachers is a set of abilities that must be possessed by a teacher so that he can carry out teaching tasks successfully ${ }^{12}$ Professional competence as

${ }^{9}$ Departemen Pendidikan Nasional. 2007. Peraturan Menteri Pendidikan Nasional Nomor 16 Tahun 2007 Tentang Standar Kualifikasi Akademik Dan Kompetensi Guru. BSNP. Jakarta: Depdiknas, 2007.

${ }^{10}$ Arifin, Kompetensi Guru dan Strategi Pengembangannya (Jakarta: Lilin Persada Press, 2011), p. 28.

${ }^{11}$ Sudarwan Danim, Inovasi Pendidikan dalam Upaya Peningkatan Profesionalisme Tenaga Kependidikan. Bandung: Pustaka Setia, 2002), p. 29.

${ }^{12}$ Hamzah B. Uno, Profesi Kependidikan Problema, Solusi dan Reformasi Pendidikan di Indonesia (Jakarta: Bumi Aksara, 2007), p. 18. 
described by Janawi that professional competence is the basic ability of education personnel is called professional, if he is able to master theoretical and practical skills and skills in the learning process. These competencies tend to refer to theoretical and practical abilities in the field. ${ }^{13}$

\section{Scope of Teacher Professional Competence}

Achmad Sanusi explained, there are at least ten basic abilities that a teacher must have. The ten basic abilities in question are as follows:

a. Teachers are required to master teaching materials.

b. Teachers are able to manage learning and teaching programs.

c. The teacher is able to manage the class.

d. Teachers are able to use media and teaching resources.

e. Teachers are able to master the foundations of education.

f. Teachers are able to manage the teaching and learning process.

g. Teachers are able to carry out teaching evaluations.

h. Teachers are able to carry out guidance and counseling services.

i. Teachers are able to make school administration.

j. Teachers are able to carry out classroom action research. $^{14}$

According to Mukhtar as quoted by Hambali that the dimensions of a teacher's professionalism indicators can be observed in the following table: ${ }^{15}$

13Janawi, Kompetensi Guru: Citra Guru Profesional (Bandung: Alfabeta, 2012), p. 48.

${ }^{14}$ Achmad Sanusi, Studi Pengembangan Model Pendidikan Profesional Tenaga Kependidikan. Laporan Penelitian (Bandung: IKIP Bandung, 2012), p. 37.

${ }^{15}$ Mukhtar, Merambah Manajemen Baru (Jakarta: Misaka Galiza, 20003), h. 98. Cited by Muh. Hambali, "Manajemen Pengembangan 
Table. 2.3 Indicators of Professional Competence

\begin{tabular}{|c|c|c|}
\hline No & Dimension & Indicator \\
\hline 1 & Competence & $\begin{array}{l}\text { a. Competence towards } \\
\text { career } \\
\text { b. Competence towards } \\
\text { work } \\
\text { c. Competence for everyone }\end{array}$ \\
\hline 2 & Responsibility & $\begin{array}{ll}\text { a. Responsibility for work. } \\
\text { b. Career responsibility. } \\
\text { c. Oriented to stakeholder } \\
\text { service. } \\
\text { d. Work according to } \\
\text { priority. } \\
\text { e. social responsibility. } \\
\text { f. Moral responsibility } \\
\text { g. Scientific responsibility }\end{array}$ \\
\hline 3 & openness & $\begin{array}{l}\text { a. Orientation to the outside } \\
\text { world. } \\
\text { b. Open to new ideas. }\end{array}$ \\
\hline 4 & $\begin{array}{l}\text { Reward and } \\
\text { Punishment } \\
\text { orientation }\end{array}$ & $\begin{array}{l}\text { a. Have certainty of wages or } \\
\text { salaries. } \\
\text { b. Have a clear status. } \\
\text { c. Prestige orientation. } \\
\text { d. Respect or have a code of } \\
\text { ethics. }\end{array}$ \\
\hline 5 & $\begin{array}{l}\text { Ability } \\
\text { Creativity }\end{array}$ & $\begin{array}{l}\text { a. Able and have the } \\
\text { behavior of a tutor. } \\
\text { b. Develop collaboration } \\
\text { norms. } \\
\text { c. Able to discuss new } \\
\text { strategies. } \\
\text { d. Able to teach. }\end{array}$ \\
\hline
\end{tabular}

Kompetensi Guru PAI." Jurnal Manajemen Pendidikan Islam (J-MPI) 1.1 (2016), p. 75-89. 


\begin{tabular}{|l|l|}
\hline \multirow{4}{*}{} & e. Able to solve problems. \\
& f. Able to analyze data. \\
& g. Able to improve strategy. \\
& h. Risk control. \\
i. Able to deal with different & human beings. \\
& j. Able to push each other. \\
& k. Have special skills. \\
& l. Have competence \\
\hline
\end{tabular}

\section{Overview of Islamic Religious Education}

National Education functions to develop capabilities and shape the character and civilization of a dignified nation in the context of educating the nation's life, aiming at developing the potential of students to become human beings who believe and fear God Almighty, have noble character, are healthy, knowledgeable, capable, creative, independent, and become democratic and responsible citizens. ${ }^{16}$

Education is an effort to develop individual potential to be able to stand alone. For this reason, individuals need to be given various abilities in the development of various things, such as cognitive, affective, psychomotor. ${ }^{17}$ In realizing change an education must start from a clear vision and mission. Schools that have a clear vision and mission will be able to map strategic plans and actions so that the changes they want to realize can be carried out effectively and efficiently. ${ }^{18}$

Darwian Shah et al, explaining that religious education Islam completely eradicated an effort to guide and care to students, so that later after completion of education can understand,

${ }^{16}$ Undang-Undang RI No. 20 Tahun 2003, Tentang Sistem Pendidikan Nasional (Jakarta: Cemerlang, 2003), p. 7.

${ }^{17}$ Nanang Fattah, Landasan Manajemen Pendidikan (Bandung: PT Remaja Rosdakarya, 2009), p. 5.

${ }^{18}$ Andang, Manajemen \& Kepemimpinan Kepala Sekolab (Yogyakarta: Ar-Ruzz Media, 2014), p. 210 
appreciate and practice the teachings of Islam completely eradicated religion as a philosophy of life for the safety and welfare of the world and the hereafter. ${ }^{19}$

Religious education Islam completely eradicated is a system that allows someone or learners can steer his life in accordance with the teachings of Islam completely eradicated. Through this approach, students will easily shape their own lives with the values of Islamic teachings that they believe in. ${ }^{20}$

According Zuhairini, Religion Islam completely eradicated is a conscious effort to lead to the formation of the personality of learners systematically and pragmatically, to live according to the teachings of Islam completely eradicated, so that the happiness of the world hereafter. ${ }^{21}$ Furthermore, Achmadi explained that Islamic Religious Education is an effort that is more specifically emphasized to develop religious nature and other human resources so that they are better able to understand, appreciate, and practice Islamic teachings. ${ }^{22}$

\section{RESEARCH METHOD}

This research is a descriptive qualitative type with a case study research design. According to Bogdan, qualitative research is like a person who wants to go on a picnic, so he just knows where he is going, but of course he doesn't know for sure what that place is. He will know after entering the object, by reading various written information, pictures,

${ }^{19}$ Darwian Syah. dkk, Pengembangan Evaluasi Sistem Pendidikan Agama Islâm (Jakarta: Diadit Media, 2009), p. 28.

${ }^{20}$ Samsul Nizar, Filsafat Pendidikan Islâm (Jakarta: Ciputat Press, 2002), p. 32.

${ }^{21}$ Zuhairi, Metodologi Pembelajaran Pendidikan Agama Islâm (Malang: UIN Press, 2004), p. 11.

${ }^{22}$ Achmadi, Islam Sebagai Paradigma Ilmu Pendidikan (Yogyakarta: Aditya Media, 1992), p. 103. 
thinking and seeing the object and the activities of the people around him, conducting interviews and so on. ${ }^{23}$

The final result of qualitative research is not only to produce data or information that is difficult to find through quantitative methods, but also to be able to produce meaningful information, even hypotheses or new knowledge that can be used to help solve problems and improve people's lives. $^{24}$

\section{RESULTS AND DISCUSSION}

The journey of the Indonesian Islamic Education Teacher Association has entered the age of fourteen where one of its missions is to pay full attention to the development of the competence of Islamic religious education teachers as figures of the people who are generally used as role models for all students inside and outside school. Of course, as exemplary figures, Islamic religious education teachers are not only expected to be able to express true Muslim morals, but also have the scientific capacity that is in line with their morals and are intelligent and creative in distributing their knowledge to students.

If personality competence only dwells on the expression and actualization of a true Muslim personality by Islamic religious education teachers, then professional competence is a skill that concerns all aspects of the Islamic religious education teacher himself. In simple terms, it can be said that a person who is able to combine emotional, intellectual, and spiritual intelligence.

Furthermore, to identify the form of professional competence of Islamic religious education teachers, it should

${ }^{23}$ Sutrisno Hadi, Statistik 1 (Yogyakarta: Penerbit Andi Offset, 1993), h. 1. Cited by Amirotun. Sholikhah, "Statistik Deskriptif dalam Penelitian Kualitatif. " Komunika: Jurnal Dakwah dan Komunikasi 10.2 (2016): p. 342-362.

${ }^{24}$ Amirotun. Sholikhah, "Statistik Deskriptif dalam Penelitian Kualitatif." Komunika: Jurnal Dakwah dan Komunikasi, p. 342-362. 
be adjusted to the juridical aspect regarding professional competence itself. With regard to professional competence, its relevance to the facts at the research site are as follows:

Mastery of Islamic religious education learning materials is the ability of a teacher to understand theories related to Islamic religious education whether it involves mastering the content of the material including the Qur'an, aqidah, morals, fiqh and history, basic juridical and theological understanding, substance, and the urgency of Islamic religious education material to be studied and taught to students. A teacher can be categorized as a professional teacher if he is able to compile and conceptualize subjects in a structured and systematic manner based on the consideration of the suitability of the material with the general characteristics of students. Meanwhile, another aspect of being a professional teacher is that he has a supportive scientific pattern.

The ability of educators in aspects of material, structure, concepts, and scientific patterns that support substantially is aimed at participants so that they should not just listen, listen, and follow the learning process but so that students are able to appreciate and understand the benefits of studying Islamic religious education. Furthermore, if the Islamic religious education teacher wants what is taught to be in accordance with the target, the skills possessed should not be channeled based on the teaching style alone without considering the learning style of the students themselves.

As for students, their development can be analogized as a ladder where each step starts from the first rung to the last rung, so professional educators have a responsibility not only to provide stairs, but to introduce students to the benefits and threats that can occur. on every step that will be tread and guide them to arrive safely. That is, the learning material that should be delivered by educators must be in accordance with the stages of their age group.

A professional educator is characterized by intelligence in mastering subject matter, professional 
development and improvement that is honed on an ongoing basis. For more details will be described as follows:

a) Mastery of Learning Materials and Structures

The hallmark of a professional Islamic religious education teacher is characterized by mastery of the material. Mastery of the material is the initial stage of professional skills, while learning material is a message to be transferred in the learning process, because the material will be delivered to students who incidentally are still in their teens, it is appropriate for educators to structure Islamic religious education learning materials based on class groups and content. graded material.

Learners with various potential intelligences need to get an equal share of education, so the learning structure is important so that education is not only intended for students who have a high IQ but also can satisfy the learning needs of students who are slow in learning. So it can be understood that the learning structure essentially refers to the mapping of learning materials from the easiest to the most difficult learning materials, while the goal is for students to understand the subject matter well.

The learning structure can be analogous to a tree, starting from the seed and then growing roots and stems, on the trunk then growing branches, stalks and leaves. In the end, the learning structure is intended as an effort to touch the structured and systematic understanding of students. An educator who is skilled in structuring learning can be considered to have understood the learning materials and learning styles of students to create a happy learning atmosphere.

Judging from their duties and responsibilities, professional educators consider that educating the nation's life is their duty and responsibility. But an educator is not enough to be limited to mastering the material, but he is required to be able to structure learning so that learning can be arranged systematically. 
The facts found at the research location indicate that in general, Islamic religious education teachers in the Selayar Islands Regency have the ability to master the material and learning structure. This was used as a reference based on the activities of the Teacher Working Group (KKG) in the field of Islamic religious education, in which Islamic religious education teachers were provided with tips for structuring learners and emphasizing mastery of teaching materials. The slight difference is the ability of Islamic religious education teachers in delivering material that tends to vary. ${ }^{25}$

Mastery of learning materials and learning structuring by Islamic religious education teachers is designed into the Learning Implementation Plan (RPP) and syllabus in which the concepts, learning implementation processes, and targets to be achieved have been determined. Abd. Rajab and Amran as teachers of Islamic religious education in the Selayar Islands, Benteng Jampea explained:

Based on the teaching capital that I understand in college and supported by experience as a teacher for several years, at least I am quite familiar with Islamic religious education learning materials. The learning process is based on the syllabus, then we design a lesson plan, the stages are in the syllabus then we formulate a lesson plan in the lesson plan, we map out starting from figh and then history. The orientation is adjusted to the material being taught, for example what is the material for the activities being taught, of course we provide motivation based on the material being taught. The learning method is adjusted to the child's ability level, according to the learning method. ${ }^{26} 27$

In line with the above explanation, Hasriani and Musdiring as teachers of Islamic religious education in the Selayar Islands Regency also explained:

\footnotetext{
${ }^{25}$ Observation, Selayar, Monday, 5 April 2021.

${ }^{26}$ Amran, teacher, interview, Wednesday, 7 April, 2021.

${ }^{27}$ Abd. Rajab, teacher, interview, 6 April, 2021.
} 
As teachers, of course, we must master the material, because when students ask questions, we can answer correctly. For mastery of the material, we don't just focus on one book. Some references and other sources of knowledge are needed, such as the use of internet media to increase teacher knowledge and insight. ${ }^{28}$

Understanding the material and structuring Islamic religious education learning needs to be done so that the learning process can be arranged systematically from the lightest to the material that tends to be difficult to understand, as students who generally get bored easily need to be introduced first to the urgency of the material to be studied so that they can understand the importance study Islamic religious education. Firsan and Haryanti as teachers of Islamic Religious Education in the Selayar Islands Regency also expressed this.

The first to prepare teaching materials then study or understand the teaching materials. in explaining learning must be systematic so that students can understand the learning material provided by the teacher. In organizing and implementing learning, first of course we teach according to the RPP that we have compiled, so that learning is more focused, and besides that, of course there are still many other administrations that we fulfill so that the learning process can run well. Tips for evaluating student learning outcomes include giving daily tests, group or individual practice, attitude assessment and semester exams. When there are students who are cognitively lacking but in terms of their good attitudes, there is a teacher's consideration, we do remedial and enrichment. ${ }^{29} 30$

Islamic religious education learning materials should begin with the introduction of educators to the characteristics

\footnotetext{
${ }^{28}$ Hasriani and Musdiring, teachers, interview, 6 April, 2021.

${ }^{29}$ Hasriani, teacher, interview, Jumat, 9 April 2021.

${ }^{30}$ Firsan, teacher, Thursday, 8 April, 2021.
} 
of the students. That is, an educator, especially an Islamic religious education teacher, should know the pattern of religious behavior of his students both inside and outside the classroom. This introduction process is intended so that Islamic religious education teachers can more easily present learning materials while the learning process is in progress.

Introduction to students is also an important consideration in conducting the concept and preparation of Learning Implementation Plans (RPP), that Islamic religious education teachers prepare RPP not only with speculation on the character of students and then adapting Islamic religious education materials based on the provisions in the curriculum, but efforts need to be made deeper introduction to ensure there is chemistry between educators and students.

Students are children who must be forged based on their potential, not based on the passions and pleasures of educators. The education process is directed not to be misled by students because some phenomena often occur where many students have extraordinary potential but are taught by incompetent educators so that they do not find their true identity.

Competent educators are the expectations of students, especially in the school environment, competent educators have the awareness and maturity to behave and are knowledgeable, consider students as work partners in supporting an unsung noble profession. So educators need to take time for students, build communication that eliminates physical barriers where students are no longer afraid or embarrassed to ask questions and educators do not lose their authority as teachers.

It should also be noted that the Indonesian people are currently experiencing a crisis of exemplary, it is very difficult to find a leader who can be used as a reference that the real indication is the spread of immoral and sad behavior that has become entrenched and even enters the spaces of educational institutions. Therefore, it is necessary to be present in the 
midst of students an exemplary teacher who inspires and is truly influential.

Influential teachers will become models and references in the lives of students. It could be that what is being referred to is his personal character, his way of teaching, his spirituality, his sincerity and various other dimensions of life. The rest, the emphasis is always on the interesting side that deserves to be imitated.

Based on the explanation above, it can be understood that the mastery of the material and learning structure of Islamic religious education teachers in the Selayar Islands Regency tends to be the same, this is also due to the design of the learning process which is prepared in the syllabus and lesson plans referred to from the same curriculum and the same material. Another thing that distinguishes educators from one another is from the aspect of skills in distributing Islamic religious education materials, some creative educators utilize learning media and some still use manual media.

b) Ability to Concept Learning

Basically, the ability referred to here is that education staff or Islamic religious education teachers are able to have a conceptual framework for student learning. If education is basically an effort to humanize humans, an educator must understand the basics of humanizing students, including an educator who must have sympathy, shame, humility, and recognize right and wrong. The love of educators for students should be the specialty of educators for students, if an educator understands the situation of knowledge drought faced by students, this sympathy will be a stimulus for educators to alleviate their intellectual crisis, it can be said that it is not much different from the concerns of a father. to his son.

The sympathy of educators who will raise their own degrees while at the same time elevating the position of students as a generation that needs to be inserted with knowledge capital for intellectual civilization in the future. 
Furthermore, with shame, an educator will be more introspective as a teacher. A professional teacher pays attention to his profession as an absolute responsibility and must feel ashamed when in a state of stupidity. Shame is always accompanied by trying to get out of embarrassing situations. If you are ashamed of being stupid, you will get out of the situation of stupidity by improving yourself.

An educator who wants to humanize humans should also have a humble personality. The humble context in this case does not monopolize the learning space but provides opportunities for students to hone their critical thinking skills. Humble educators will always share their knowledge with students so that they are able to perform together in the future.

The rest, educators who want to humanize humans have awareness in identifying their own actions about right and wrong. Humanizing humans in the context of right and wrong can simply be interpreted as a view of the existence of students who have various potentials, if this view is embedded in the personality of educators, there will be no justification and categorization of stupid students and smart students. This needs to be understood because mistakes are human while the truth is ideals, what needs to be emphasized is that all students have the desire to learn and improve their quality.

Regarding the concept of learning in terms of practice, Abd. Rajab SMPN 7 Selayar Islands Benteng Jampea explained that:

In applying learning theory, I am more dominant in applying the cognitive aspect, so the process before learning I convey the SK-KD first then the learning only provides an explanation of the material, after that I give the children the opportunity to discuss what I have said, at the end My new activity is evaluating. ${ }^{31}$

${ }^{31}$ Abd. Rajab, teacher, interview, Tuesday, 6 April, 2021. 
Returning to conceptualized and planned learning, this term is different from learning which is only done to abort obligations. A good Islamic religious education teacher is a teacher who teaches and makes full efforts to touch the potential of students, be it their physical, psychological, and emotional potential. Sometimes students are only physically active, receive the material transferred by the educators, but do not animate the material obtained, finally in different situations students tend to forget easily.

Conceptual learning can also be said to be a manifestation of the substance of education itself which in terminology is interpreted as "conscious" and "planned" efforts. The conscious effort in question is full awareness of professional responsibilities, while the planned aspect is a series of activities that have been ripe to be delivered to students and are in accordance with the needs of students.

As explained in the sub-point of the previous chapter, the structuring of learning materials is arranged in the syllabus and Learning Implementation Plan (RPP), which in general, every teacher of Islamic religious education has the same skills. But in the implementation process, educators differ in actualizing learning materials in classrooms.

Differences in teaching tend to vary due to differences in the models and learning methods used as well as the different characters of students, which requires educators to adjust teaching techniques according to students' learning styles. Firsan, as a teacher of Islamic religious education at SMKN 8 Selayar, Bontosikuyu District, Selayar Islands Regency explained that:

Regarding the ability of Islamic religious education teachers in the concept and application of learning theory, of course we know that the teacher can function as a facilitator, then of course when we want to facilitate the student learning process, in conveying theory, the 
language used is easy to understand language. the student himself. ${ }^{32}$

The basic concepts of Islamic religious education learning should be prepared based on the teacher's understanding of learning, the introduction of educators to students, the ability of educators to transfer knowledge with various methods and models, as well as the skills of educators in the functioning of supporting learning facilities such as technology or other means. In the end, professional educators must be skilled in conceptualizing learning so that students can easily understand what is conveyed in the learning process.

The learning concept in question is polarization and mapping compiled by Islamic religious education teachers in making a mature learning schedule. Thus, the ability to conceptualize learning exists as a product of educator thinking, either individually or in groups so that the learning process can be realized effectively from the aspect of material content and efficient from the time aspect.

Regarding the ability of Islamic religious education teachers in conceptualizing learning, Firsan also added that:

Quality of teaching, in the process of teaching examples of learning about prayer sometimes we provide examples through pictures and sometimes we also practice prayer directly. However, the result is that there are those who understand and others who do not understand. For students who do not understand we provide some kind of guidance or enrichment. There are three things that in collaborating knowledge, understanding and ethical values, especially as a teacher, first his words must be in accordance with his understanding and actions because when they are not the same then they are not directly proportional and the values themselves will be much different. Another

${ }^{32}$ Firsan, teacher, interview, Thursday, 8 April, 2021. 
example is when we tell students about worship, we also do it. ${ }^{33}$

The concept of learning basically contains an emphasis on the learning process based on the learning model used so that learning activities can be carried out by maximizing and involving the active role of educators and students. In order for learning to touch the potential of students (cognitive, affective, and psychomotor) then the teaching style of educators and learning styles of students must be integrated, it can be said that between educators and students should blend.

The concept of learning should be structured based on the orientation of the subjects being taught, which orientation includes the learning process strategy to achieve the target. The facilities and infrastructure that support the learning process of Islamic religious education are used absolutely according to the subjects and are believed to be pleasing to the students.

Regarding learning orientation, I think this is related to the introduction of attitudes and how we recognize our own personality and the personality of our students so that through our own personality as religious teachers we will motivate students because a teacher should be an example for their students. When motivation can be built, the mission or criteria to be achieved can be realized so that the objectives of PAI learning, which are basically focused on moral improvement, can be achieved properly. ${ }^{34}$

As Islamic religious education subjects whose orientation is not only aspects of cognition, but the emphasis is on the inspiration for the material and the practice of the values learned. So the concept of Islamic religious education learning materials should be able to skillfully touch the three

${ }^{33}$ Amran dan Firsan, teachers, interview, Thursday, 8 April, 2021.

${ }^{34}$ Firsan, teacher, interview, Thursday, 8 April, 2021. 
potential students in question, namely physical (involvement), psychological (inspiration), and emotional (actualization). While in the aspect of conceptualizing the material, Islamic religious education teachers are required to understand the character of students as a consideration in creating creative and innovative learning processes. The learning objectives that have been conceptualized from the planning stage to the evaluation stage are directed to match the understanding of the material and the introduction of the characteristics of students.

First, a teacher must have basic concepts such as lesson plans or learning tools and besides that we take part in various trainings to improve the development of PAI learning. Regarding the mastery or analysis of the material, it must be conditioned to the student's condition without reducing the agreed concept. The initial step taken, the teacher must recognize the character and character of the student then after getting to know the student's character, to increase student interest in learning, the teacher must adapt the learning method to the student's situation even though the method is different but the purpose of learning is the same. $^{35}$

Based on the explanation above, it can be understood that in general the concept of learning Islamic religious education organized by Islamic religious education teachers in the Selayar Islands Regency tends to refer to the syllabus and Learning Implementation Plan (RPP). Although basically the concept of learning is adapted to the needs of students, in other contexts educators should have a distinctive style of teaching. It should also be understood that the concept of learning is not rigid in one place, meaning that an interesting learning process can be realized anywhere. For example, in

${ }^{35}$ Amran dan Firsan, interview, Wednesday, 8 April, 2021. 
learning Islamic religious education such as hajj fiqh, this can be done outside the classroom because it requires practice or simulation.

Emphasizing that learning absolutely must be done in the classroom seems too rigid, a creative educator will be sensitive to situations faced by students, such as how easily they feel bored in learning. To anticipate this problem, an educator can conceptualize learning that is sometimes done outside the classroom or by using the rihlah method. This method is often used by Abd. Rajab as a teacher of Islamic religious education at SMPN 7 Benteng Jampea as explained.

In my teaching system, I don't just focus on one room, sometimes I take children out of the room and sit under a tree to discuss and indeed with this method the results are quite significant. I have applied this method several times and indeed the students' absorption of the subject matter is quite good. Sometimes to make learning fun, I make a game. Each group competes to formulate something depending on the material being taught. ${ }^{36}$

Meanwhile, the results of interviews conducted with Firsan as a teacher of Islamic religious education in the Selayar Islands Regency explained that:

In terms of evaluating, specifically what I usually apply, for example before starting a lesson, I usually reflect on the previous day's lessons to find out how far the child's understanding of the lessons I give. at the time of delivery of theory to determine the ability of our children to provide exercises in accordance with learning theory, especially for practice so to see the ability of children in practice, we provide an evaluation through the practice itself. ${ }^{37}$

${ }^{36}$ Abd. Rajab, teacher, Tuesday, 6 April, 2021.

${ }^{37}$ Firsan, 'Wawancara' Guru Pendidikan Agama Islam SMKN 8 Selayar Kecamatan Bontosikuyu Kabupaten Kepulauan Selayar, Kamis 8 April, 2021. 
Based on the results of the interviews above, it can be understood that the learning process is not just a transfer of knowledge from educators to students, there is an advanced stage for students after gaining knowledge, namely trying to think critically. This stage is important so that students do not just receive and collect material, but they are also expected to be able to detect the urgency and value of the material taught by educators. Lately, education has experienced a decline in quality because learning is directed at achieving value in terms of numbers, while value in terms of value tends to get less attention. The concept of learning should be dominated by the decomposition of the value (value) so that learners are able to understand the importance of learning.

\section{CONCLUSION}

Judging from the discussion and research results in the previous sub-chapter, the conclusions of this study can be described as follows:

1. The professional competence of Islamic religious education teachers in Selayar Islands Regency varies, this is due to the different capacity factors of Islamic religious education teachers, and limited access to supporting facilities, especially in islands, inland or remote areas.

2. The contribution of the Regional Board of the Association of Indonesian Islamic Religious Education Teachers DPD AGPAII Selayar Islands Regency is affiliated with relevant agencies, opening PAI teacher training rooms, mentoring PAI teachers, intensity of discussions via social media and monthly meeting agendas, as well as motivation and strengthening of PAI teacher skills.

3. The results of the professional competence development of PAI teachers in the Selayar Islands Regency are to help achieve the goals of the Islamic religious education teacher profession, improve the 
quality of Islamic religious education learning, maximize empowerment and use of technology. The results of this effort are considered to have increased from before.

\section{REFERENCES}

A. Tabrani, Z. "Exploring Educational Methods in the Al-

Quran with Maudhui's Tafsir Approach." Porch of Tarbawi 2.1. 2014.

Al-'Asqalani, Ibn Hajar. Fath al-Bârî bi Syarh Saḥ̂h Bukhârî, Volume 3. Beirut : Dar al-Fikr, t.th. al-Kitâb al-Janâiz, al-Bâb Mâ Qîla fî Awlâd al-Mushrikîn, Hadith Number 1385.

Al-Bani, Muhammad Nasiruddin. Sabih Bukhari Summary . Volume I, Cet. III; Azzam Library, 2007.

al-Harahap, Wahida Syafitri. Supervision of Madrasah Heads in Realizing the Character of Teachers with Characteristics of Karimah at Mts Madinatussalam Tembung. Medan: Uinsu, 2016.

Al-Mubarakfûrî. Tubfah al-Abwâdzî Syarh Jami' al-Tirmidhî , Juz 7. Beirut: Dâr al-Fikr, 1979. Al-Kitâb: al-'Ilm 'an Rasûl Allâh ; al- Bab: Mâ Jấa fì Fadl al-Fiqh 'Alâal-'Ibâdah. ; Hadith number: 2825.

Amen. Teaching Profession. Medan: Perdana Publishing, 2013.

Amir, Asfar et al. "The Influence of Teacher Competence on the Work Achievement of State High School Teachers in Kota Pariaman, West Sumatra" Management Research Journal Vol. 5, No. 1, 103 - 118 ISSN 2232 - 0660103. 2015.

Torch. Principal Management \& Leadership. Yogyakarta: ArRuzz Media, 2014. 
Aniek Indrawati "The Influence of Service Quality of Educational Institutions on Consumer Satisfaction." Journal of Business Economics 16.1. 2011.

Anshori . Islamic Education Transformation . Jakarta: Echoes of Persada Press, 2010.

Arifin, M. Islamic Education: A Theoretical and Practical Review Based on an Interdisciplinary Approach. Jakarta: Earth Literacy, 2006.

Arikunto, Suharsimi. Research Procedures: A Practical Approach . Jakarta: Rineka Cipta, 2006.

Asmani, Jamal Ma'mur. Tips for Becoming an Inspirational, Creative, and Innovative Teacher. Yogyakarta: Diva Press, 2011.

Assa, Enar Ratriany. Strategy Of Learning . Yogyakarta: Araska, 2015.

Bhakti, Caraka Putra et al. "LPTK's Strategy in Developing Pedagogic Competence for Guidance and Counseling Teacher Candidates", Faculty of Teacher Training and Education, Ahmad Dahlan University. Journal of Education 2527-689198 Volume 1 Number 2 of 2016. Daradjat, Zakiah et al, Islamic Education . Jakarta: Earth Literacy, 2012.

Department of Education and Culture. Big Indonesian Dictionary. Balai Pustaka, 2007.

The Central Executive Board (DPP) of the Association of Indonesian Islamic Religious Education Teachers . AGPAII's Articles of Association and Bylaws . Asem Baris Raya Jl. K No. 20 Kebon Baru Tebet, South Jakarta Jakarta-Indonesia, 2017.

Djamarah, Syaiful Bahri. Teachers and Students in Educational Interaction: A Psychological Theoretical Approach . cet. II; Jakarta: Rineka Cipta, 2010.

Esposito. The Oxford Encyclopedia of the modern Islamic World. Volume; IV, New York: Oxford University Press, 1995. 
Farikhah, Siti. Management of Educational Institutions . cet. I; Yogyakarta : Aswaja Pressindo, 2015.

Fattah, Nana. Educational Management Foundation. Bandung: PT Youth Rosdakarya, 2009.

Gunawan, Imam. Qualitative research methods. Jakarta: Earth Literacy, 2013.

Hamalik, Oemar. Teacher Education Based on Competency Approach. cet. IV; Jakarta: Earth Literacy, 2006.

Hambali, Moh. "Management of PAI teacher competency development." Journal of Islamic Education Management (J-MPI) 1.1. 2016.

Hi, Akmal. Islamic Religious Education Teacher Competence. Jakarta: PT. Raja Grafindo Persada, 2013.

Ismail Darimi. "Improving the Pedagogic Competence of PAI Teachers in Learning." Mudarrisuna Journal: Media for the Study of Islamic Religious Education 5.2. 2015. 